Terakreditasi

Ditjen Penguatan Riset dan Pengembangan, Kemenristekdikti

Keputusan No: 21/E/KPT/2018, Tanggal 9 Juli 2018
Mei 2019, 6(2):161-165

DOI: http://dx.doi.org/10.33772/jitro.v6i2.7106

http://ojs.uho.ac.id/index.php/peternakan-tropis

\title{
Kadar NPK Feses Domba Garut yang Diberi Ransum Mengandung Silase Daun Rami (Boehmeria nivea)
}

\author{
Budi Ayuningsih*, Ana Rochana, Iman Hernaman, Rahmat Hidayat, Tidi Dhalika \\ Fakultas Peternakan Universitas Padjadjaran, Jalan Raya Bandung-Sumedang Km. 21, \\ Jatinangor, Sumedang 45363 \\ *Email korespondensi: budiayuningsih@gmail.com
}

(Diterima: 24-02-2019; disetujui 10-04-2019)

\begin{abstract}
ABSTRAK
Penelitian bertujuan mengevaluasi ransum mengandung silase daun rami (Boehmeria nivea) terhadap kandungan BK dan NPK feses domba garut. Penelitian menggunakan rancangan acak lengkap (RAL) dengan empat perlakuan, yaitu $\mathrm{R} 1=100 \%$ rumput $\mathrm{R} 2=60 \%$ rumput $+40 \%$ konsentrat, $\mathrm{R} 3=$ $30 \%$ silase daun rami $+30 \%$ rumput $+40 \%$ konsentrat, $\mathrm{R} 4=60 \%$ silase daun rami $+40 \%$ konsentrat. Masing-masing perlakuan diulang sebanyak lima kali. Data hasil penelitian dianalisis ragam dan dilanjutkan uji jarak berganda Duncan. Hasil penelitian menunjukkan bahwa penggunaan silase daun rami sampai tingkat $60 \%$ dalam ransum domba garut nyata mempengaruhi $\mathrm{BK}$, kadar abu dan $\mathrm{K}(\mathrm{P}<0,05)$, tetapi tidak mempengaruhi kandungan $\mathrm{N}$ dan $\mathrm{P}$ feses domba. Pemberian silase daun rami sebanyak $60 \%$ dalam ransum menghasilkan kandungan abu feses tertinggi $(25,49 \%)$ serta menghasilkan 33,55-40,89\% $\mathrm{BK}, 2,27-2,53 \% \mathrm{~N}, 0,57-0,67 \% \mathrm{P}$ dan $0,21-0,34 \% \mathrm{~K}$. Kesimpulan, penggunaan silase daun rami sampai tingkat $60 \%$ berpotensi sebagai pupuk organik dalam menyediakan unsur N,P, dan K bagi tanaman.
\end{abstract}

Kata Kunci : domba garut, daun rami, feses, NPK, silase

\section{ABSTRACT}

The study aimed to evaluate the ration containing silage of Boehmeria nivea leaf on the dry matter (DM) and N, P, K content of garut sheep feces. The study used a completely randomized design (CRD) with four treatment, namely $\mathrm{R} 1=100 \%$ grass; $\mathrm{R} 2=60 \%$ grass $+40 \%$ concentrate; $\mathrm{R} 3=30 \%$ silage of Boehmeria nivea leaf $+30 \%$ grass $+40 \%$ concentrate; and $\mathrm{R} 4=60 \%$ silage of Boehmeria nivea leaf + $40 \%$ concentrate. Each treatment was repeated five times. The data obtained were analyzed by variance of analysis and continued with Duncan's multiple range test. The results showed that the use of Boehmeria nivea leaf silage up to $60 \%$ in garut sheep ration significantly affected the dry matter (DM), ash, and K content ( $\mathrm{P}<0.05)$, but did not affect the $\mathrm{N}$ and $\mathrm{P}$ content of sheep feces. Giving silage of Boehmeria nivea leaf up to $60 \%$ in the ration produced the highest fecal ash content $(25.49 \%), 33.55-40.89 \%$ DM, 2.27$2.53 \% \mathrm{~N}, 0.57-0.67 \% \mathrm{~N}$ and $0.21-0.34 \% \mathrm{~K}$. This research concludes that the use of Boehmeria nivea leaves silage up to $60 \%$ has the potential as an organic fertilizer in providing $\mathrm{N}, \mathrm{P}$, and $\mathrm{K}$ elements for plants.

Keywords: Boehmeria nivea leaves, feces, garut sheep, NPK, silage

\section{PENDAHULUAN}

Penggalian potensi pakan yang bersumber dari perkebunan atau agroindustri guna mengatasi kelangkaan pakan sudah sangat diperlukan. Salah satu agroindustri yang menghasilkan limbah berupa daun adalah industri serat rami (Boehmeria nivea). Industri serat rami menghasilkan limbah berupa daun rami segar dengan jumlah mencapai $40 \%$ dari total berat tanaman rami (Tirtosuprobo et al., 2007). 
Potensi nutrien daun rami sangat baik sebagai pakan karena mengandung protein cukup tinggi berkisar $21-25 \%$ dari bahan keringnya, lemak kasarnya dapat mencapai $2 \%$ dan kandungan NDF-nya berkisar 44-52\%.

Kandungan protein dan kadar air yang tinggi menyebabkan daun rami mudah membusuk, sehingga membutuhkan proses pengawetan terutama ketika ketersediaan daun rami melimpah pada musim panen serat rami. Daun rami segar dengan kandungan air yang tinggi lebih cocok jika diawetkan dengan pembuatan silase. Teknik ini selain mengawetkan limbah pertanian juga lebih aman dan dapat memberikan nilai nutrisi yang lebih baik, selain itu perlakuan silase dapat mempertahankan kondisi limbah tersebut tetap dalam keadaan segar dan mampu mempertahankan zat-zat yang terkandung dari bahan yang dibuat silase (Hernaman et al., 2005). Silase daun rami dapat menyediakan pakan ruminansia yang berkualitas.

Pemberian daun rami lebih dari 50\% total ransum tidak memberi pengaruh yang negatif pada ternak Ruminansia (Balai Penelitian Ternak, 2008). Salah satu ternak ruminansia yang dapat memanfaatkan daun rami adalah domba garut. Domba garut adalah domba yang banyak dijumpai di wilayah Jawa Barat, dan merupakan rumpun domba asli dari Jawa Barat. Pemberian silase daun rami diharapkan dapat menyediakan pakan saat musim kemarau, disisi lain pemeliharaan domba yang diberi daun rami juga menghasilkan feses yang berpotensi sebagai pupuk.

Pupuk merupakan salah satu komponen penting dalam peningkatan produksi tanaman. Penggunaan pupuk mulai bergeser dari kimia menjadi organik. Penggunaan pupuk organik dalam jangka panjang dapat meningkatkan produktivitas lahan dan dapat mencegah degradasi lahan. Pupuk organik mempunyai fungsi yang penting dibandingkan dengan pupuk anorganik, selain menyediakan unsur hara juga dapat menggemburkan lapisan permukaan tanah (topsoil), meningkatkan populasi jasad renik, mempertinggi daya serap dan daya simpan air, yang secara keseluruhan dapat meningkatkan kesuburan tanah (Rastiyanto et al. 2013).

Pupuk organik mengandung unsur $\mathrm{N}, \mathrm{P}$, dan K. Nitrogen merupakan unsure penting dalam pertumbuhan dan perkembangan semua jaringan hidup (Brady \& Weil, 2002) terutama pembentukan klorofil, protoplasma, protein, dan asamasam nukleat. Fosfor digunakan untuk penyusun sistem informasi genetik (DNA dan RNA), membrane sel (fosfolipid), dan fosfoprotein serta senyawa untuk transfer energi (ATP dan nukleoprotein lain) (Gardner et al., 1991; Lambers et al., 2008). Tanah yang porous seperti regosol dosis yang digunakan biasanya sebesar 250-300 kg/ha urea (sumber N) dan $100 \mathrm{~kg} / \mathrm{haSP}$ 36 (sumber P) (Wirawan \& Wahab, 1996), sedangkan pada tanah latosol diperlukan 400 $\mathrm{kg} / \mathrm{ha}$ urea dan $300 \mathrm{~kg} / \mathrm{ha}$ SP36 (Wijaya \& Wahyuni, 2007).

Unsur $\mathrm{K}$ memegang peranan penting di dalam metabolisme tanaman antara lain terlibat langsung dalam beberapa proses fisiologis, yaitu berperan dalam pengendalian tekanan osmotik, turgor sel, stabilitas $\mathrm{pH}$, dan pengaturan air melalui kontrol stomata, aktivitas enzim pada sintesis karbohidrat dan protein, serta meningkatkan trans lokasi fotosintat dari daun, memperkuat dinding sel dan terlibat di dalam proses lignifikasi jaringan sclerenchyma, meningkatkan ketahanan tanaman terhadap penyakit tertentu (Taiz \& Zeiger, 2002; Fageria et al., 2009). Kebutuhannya untuk tanaman dalam jumlah yang tinggi, yaitu berkisar antara 50-300 $\mathrm{kg} \mathrm{K} / \mathrm{ha} /$ musim tanam (Laegreid et al., 1999).

Penelitian bertujuan mengamati produksi dan kualitas feses domba garut yang mengkonsumsi silase daun rami, guna membantu menyediakan pupuk organik.

\section{MATERI DAN METODE}

Penelitian ini menggunakan 20 ekor domba garut jantan dengan umur 7-8 bulan dengan bobot badan rata-rata $17 \mathrm{~kg}+2,89 \mathrm{~kg}$. Domba dibagi atas 4 kelompok perlakuan dan masing- masing kelompok perlakuan terdiri atas 5 ekor domba. Domba diperoleh dari UPTD Balai Pengembangan dan Perbibitan Ternak Domba dan Kambing Margawati Garut, Jawa Barat.

Ransum penelitian terdiri atas 1) rumput, merupakancampuran delapan spesies rumput yang mengandung 19,95\% bahan kering (BK), $12,09 \%$ protein kasar (PK), dan 10,57\% abu, 2) silase daun rami yang mengandung $22,35 \% \mathrm{BK}$, $18,78 \%$ PK, dan $21,21 \%$ abu. Daun rami diperoleh dari perkebunan rami yang terletak di 
Desa Margamulya, Kecamatan Cikajang, Kabupaten Garut, dan 3). Konsentrat, terdiri atas $30 \%$ ampas kecap, $12 \%$ dedak halus, $10 \%$ onggok, 26\% bungkil kelapa, dan $22 \%$ pollard. Kandungan nutrien konsentrat adalah $87,35 \%$ BK, $18,60 \%$ PK, dan 10,41\%abu.

Komposisi ransum penelitian terdiri atas $60 \%$ pakan sumber serat dan $40 \%$ konsentrat. Susunan ransum penelitian adalah:

$\mathrm{R} 1=100 \%$ rumput

$\mathrm{R} 2=60 \%$ rumput $+40 \%$ konsentrat

$\mathrm{R} 3=30 \%$ silase daun rami $+30 \%$ rumput $+40 \%$ konsentrat

$\mathrm{R} 4=60 \%$ silase daun rami $+40 \%$ konsentrat Komposisi ransum mengacu pada kebutuhan nutrien domba muda (R2/ransum kontrol) untuk bobot badan $17 \mathrm{~kg}$ dengan pertambahan bobot badan $60 \mathrm{~g} /$ hari, yaitu $589,6 \mathrm{~g}$ BK, 55,12 g PK (9,35\%), dan 337,6g TDN $(57,26 \%)$ (Kearl, 1982). Ternak dipelihara menggunakan kandang panggung, individual. Koleksi feses dilakukan menggunakan celana/popok domba berupa jaring plastik berpori halus. Sampel feses kemudian dianalisis kandungan nitrogen $(\mathrm{N})$, phospor $(\mathrm{P})$ dengan metode AOAC, (2005) dan kalium (K) dianalsis dengan menggunakan alat atomicabsorbance spectrophotometry (AAS).

Penelitian menggunakan rancangan acak lengkap dan data yang diperoleh dianalis ragam dan dilanjutkan dengan Uji Jarak Berganda Duncan (Gaspersz, 1995).

\section{HASIL DAN PEMBAHASAN}

Hasil penelitian menunjukkan bahwa kandungan BK feses dan kadar abu (Tabel 1) meningkat $(\mathrm{P}<0,05)$ seiring dengan meningkatnya penggunaan silase daun rami. Kandungan BK feses perlakuan R3 dan R4 (40,89 dan 40,41\%) nyata lebih tinggi $(\mathrm{P}<0,05)$. Hal tersebut menunjukkan bahwa BK feses domba R3 dan R4 memiliki potensi sebagai pupuk organik yang dapat menyuburkan tanaman dan meningkatkan bobot segar dan daun tanaman (Rastiyanto et al. 2013; Roidah, 2013). Kadar BK feses yang meningkat disebabkan oleh meningkatnya $(\mathrm{P}<0,05)$ kandungan abu feses (Tabel 1). Hal ini karena komponen BKmeliputi kadar abu dan bahan organik, sehingga meningkatnya kadar abu juga akan meningkatkan kandungan BK.
Kandungan BK feses hasil penelitian (33,5540,89\%) masih lebih rendah dibandingkan Mathius (1994) yaitu 40-50\%.

Sementara itu, kadar abu feses meningkat nyata $(\mathrm{P}<0,05)$ seiring dengan peningkatan penggunaan silase daun rami dalam ransum. Kandungan abu tertinggi dihasilkan oleh perlakuanR4 $(25,49 \%)$ yaitu $60 \%$ silase daun rami. Peningkatan kandungan abu tersebut disebabkan oleh kandungan abu silase daun rami yang tergolong tinggi $(21,21 \%)$ dibandingkan rumput $(10,57 \%)$ atau konsentratnya $(10,41 \%)$. Hal ini menunjukkan bahwa semakin tinggi penggunaan silase daun rami dalam ransum, maka semakin meningkat pula kadar abu feses yang dihasilkan. Tingginya kadar abu dalam ransum menyebabkan terdapat sejumlah abu/mineral yang tidak tercerna dan tidak diabsorbsi oleh ternak, yang akhirnya diekskresikan dalam feses.

Kandungan $\mathrm{N}$ dan $\mathrm{P}$ feses tidak dipengaruhi oleh perlakuan, sedangkan $\mathrm{K}$ feses memperlihatkan pengaruh sebaliknya $(\mathrm{P}<0,05)$. Perlakuan R2 memperlihatkan persentasi $\mathrm{K}$ yang paling tinggi diantara perlakuan yang lain. Kondisi tersebut menunjukkan bahwa terdapat efisiensi pemanfaatan $\mathrm{N}$ dan $\mathrm{P}$ ransum perlakuan oleh domba secara baik. Hal ini membuktikan pula bahwa penggunaan silase daun rami sampai $60 \%$ dalam ransum dapat menggantikan penggunaan $100 \%$ rumput. Kandungan $\mathrm{N}$ feses hasil penelitian berkisar antara 2,27-2,53\%, mendekati kisaran secara umum 1,2-2,1\% (Mathius, 1994). Nitrogen (N) dan Fosfor (P) merupakan unsur hara yang sangat dibutuhkan oleh tanaman dalam jumlah yang besar. Nitrogen merupakan unsur penting dalam pembentukan klorofil, protoplasma, protein, dan asam-asam nukleat. Pertumbuhan dan perkembangan semua jaringan hidup membutuhkan $\mathrm{N}$ (Fahmi et al., 2010). Fosfor merupakan komponen penting penyusun senyawa untuk transfer energi (ATP dan nukleoprotein lain), untuk membran sel (fosfolipid), sistem informasi genetik (DNA dan RNA) serta fosfoprotein (Fahmi et al., 2010).

Kandungan $\mathrm{K}$ feses hasil penelitian berkisar antara 0,21-0,37\%. Kandungan $\mathrm{K}$ feses tertinggi $(0,37 \%)$ dihasilkan oleh perlakuan yang tidak menggunakan silase daun rami. Ransum pada R2 mengandung 60\% rumput dan $40 \%$ konsentrat, kontribusi kandungan $\mathrm{K}$ dalam 
rumput dan konsentrat diduga memberikan nilai $\mathrm{K}$ yang tinggi pada feses. Pemupukan $\mathrm{K}$ disamping pupuk $\mathrm{N}$ dan $\mathrm{P}$ secara berimbang, membuat pertumbuhan pada tanaman menjadi lebih baik, tahan kerebahan, tahan terhadap hama dan penyakit serta kualitasnya dapat meningkat (Alfons \& Aryantoro, 1993). Kalium merupakan unsur hara yang sangat peka terhadap pencucian, terutama di daerah tropik dengan curah hujan yang tinggi sehingga $\mathrm{K}$ dalam tanah sering ditemui sebagai faktor pembatas. Penggunaan kotoran domba diharapkan dapat mensuplai $\mathrm{K}$ untuk memenuhi kebutuhan tanaman.

Tabel 1. Pengaruh perlakuan terhadap kandungan bahan kering, abu, N, P, dan K feses domba garut.

\begin{tabular}{lcccc}
\multirow{2}{*}{ Peubah } & \multicolumn{4}{c}{ Perlakuan } \\
\cline { 2 - 4 } & R1 & R2 & R3 & R4 \\
\hline BK (\%) & $33,55 \pm 1,52^{\mathrm{a}}$ & $33,77 \pm 3,37^{\mathrm{a}}$ & $40,89 \pm 1,79^{\mathrm{b}}$ & $40,41 \pm 5,59^{\mathrm{b}}$ \\
Abu (\%) & $19,47 \pm 0,48^{\mathrm{a}}$ & $18,67 \pm 0,35^{\mathrm{a}}$ & $22,55 \pm 0,87^{\mathrm{b}}$ & $25,49 \pm 0,89^{\mathrm{c}}$ \\
N (\%) & $2,29 \pm 0,38$ & $2,53 \pm 0,18$ & $2,27 \pm 0,29$ & $2,37 \pm 0,29$ \\
P (\%) & $0,62 \pm 0,08$ & $0,57 \pm 0,10$ & $0,67 \pm 0,08$ & $0,64 \pm 0,09$ \\
K (\%) & $0,27 \pm 0,06^{\mathrm{ab}}$ & $0,37 \pm 0,05^{\mathrm{b}}$ & $0,21 \pm 0,03^{\mathrm{a}}$ & $0,26 \pm 0,11^{\mathrm{ab}}$ \\
\hline
\end{tabular}

Keterangan : Superskrip berbeda pada baris yang sama menunjukkan berbeda nyata $(\mathrm{P}<0,05)$. $\mathrm{N}=$ nitrogen, $\mathrm{P}=$ phosphor, $\mathrm{K}=$ kalium, $\mathrm{R} 1=100 \%$ rumput, $\mathrm{R} 2=60 \%$ rumput $+40 \%$ konsentrat, $\mathrm{R} 3=30 \%$ silase daun rami $+30 \%$ rumput $+40 \%$ konsentrat, $\mathrm{R} 4=60 \%$ silase daun rami $+40 \%$ konsentrat

\section{KESIMPULAN}

Penggunaan silase daun rami sampai tingkat $60 \%$ berpotensi sebagai pupuk organik dalam menyediakan unsur N,P, dan K bagi tanaman.

\section{UCAPAN TERIMA KASIH}

Terima kasih disampaikan pada UPTD Balai Pengembangan dan Perbibitan Ternak Domba dan Kambing Margawati Kabupaten Garut, Dinas Ketahanan Pangan dan Peternakan Provinsi Jawa Barat yang telah mendukung dan memberikan fasilitas penelitian.

\section{DAFTAR PUSTAKA}

AOAC. 2005. Official Methods of Analysis. Association of Official Analytical Chemists. $16^{\text {th }} \mathrm{ed}$. Washington DC. USA.

Alfons, J.B. \& Aryantoro. 1993. Populasi dan pemupukan $\mathrm{N}$ dan $\mathrm{K}$ tanaman jagung varietas TC 1 di Seram Maluku. Jurnal Agribisnis dan Perikanan 8(1):85-89.

Balai Penelitian Ternak. 2008. Daun Rami Sumber Pakan Alternatif. Balai Penelitian Ternak. Bogor.
Brady, N.C. \& R.R. Weil. 2002, The Nature and Properties of Soils. 13th Edition. Upper Saddle River, New Jersey. USA.

Fageria, N.K., M.P.B. Filho, \& J.H.C. Da Costa. 2009. Potassium in the Use of Nutrients in Crop Plants. CRC Press Taylor \& Francis Group, Boca Raton, London, New York.

Fahmi, A., Syamsudin, S.N.H Utami, \& B. Radjagukguk. 2010. Pengaruh interaksi hara nitrogen dan fosfor terhadap pertumbuhan tanaman jagung (Zea mays L.) pada tanah regosol dan latosol. Berita Biologi 10(3): 297-304.

Gardner F.P., R.B. Pearce, \& R.L. Mitchell. 1991. Fisiologi Tanaman Budidaya. Ul Press. Jakarta.

Gaspersz, V. 1995. Tehnik Analisis dalam Penelitian Percobaan. Transito. Bandung.

Hernaman, I., R. Hidayat \& Mansyur. 2005. Pengaruh penggunaan molases dalam pembuatan silase campuran ampas tahu dan pucuk tebu kering terhadap nilai $\mathrm{pH}$ dan komposisi zat-zat makanannya. Jurnal Ilmu Ternak 5(2):94-99.

Kearl, L.C. 1982. Nutrient requirements of ruminants in developing countries. 
Int'1Feedstuff. Utah Agric. Exp.Sta. USU Logan Utah USA.

Lambers, H., F.S. Chapin, \& T.L. Pon. 2008. Plant Physiological Ecology. Springer.

Laegreid, M., O.C.Bockman \& O. Kaarstad. 1999. Agriculture, Fertilizers and the Environment. CABI Publishing in Association with Norsk Hydro ASA.

Mathius, I.W. 1994. Potensi dan pemanfaatan pupuk organik asal kotoran kambing-domba. Wartazoa 3(2-4):1-8.

Rastiyanto, A.E., Sutirman, \& A. Pullaila. 2013. Pengaruh pemberian pupuk organik kotoran kambing terhadap pertumbuhan dan hasil tanaman kailan (Brassica oleraceae. L). Buletin Ikatan 3(2):36-40.

Roidah, I.S. 2013. Manfaat penggunaan pupuk organik untuk kesuburan tanah. Jurnal
Universitas Tulungagung Bonorowo 1(1): $30-42$.

Taiz, L. \& E. Zeiger. 2002. Plant Physiology. Sinauer Associates, Inc., Publisher. Sunderland, Massachusetts.

Tirtosuprobo, S., B.W. Winarto, \& M. Sahid. 2007. Peluang Pengembangan Rami Untuk Suplemen Kapas. Prosiding Lokakarya Nasional Kapas dan Rami. Balai Penelitian Tanaman Pemanis dan Serat Malang. Surabaya, 15 Maret 2006. Hlm.167-173.

Wijaya \& S. Wahyuni. 2007. Respon tanaman jagung manis kultivar Hawaian super sweet pada berbagai takaran pupuk kalium. Jurnal Agrijati 6(1):42-47.

Wirawan G.M. \& M.I. Wahab. 1996. Rakitan Paket Teknologi untuk Mendukung Program Peningkatan Produksi Jagug di Jawa Timur. Bimas Provinsi Jawa Timur. 